\title{
Biological activity of soils cultivated with yacón (Smallanthus sonchifolius Poep. \& Endl) H. Robinson, inoculated with Azospirillum brasilense and native mycorrhizal fungi
}

\author{
Actividad biológica de suelos cultivados con yacón (Smallanthus sonchifolius \\ Poep. \& Endl) H. Robinson, inoculados con Azospirillum brasilense \\ y hongos micorrícicos nativos
}

Gabriela Di Barbaro"; Horacio Andrada²; Eleodoro Del Valle³; Celia Brandán de Weht ${ }^{4}$.

\begin{abstract}
ARTICLE DATA
1. Professor, Esp. National University of Catamarca. Argentina, gabydibarbaro@yahoo.com.ar

2. Professor, MSc. National University of Catamarca. Argentina, horacio_andrada@yahoo.com.ar

3. Professor, DSc. Ciagro Litoral, National University of the Litoral, CONICET. Santa Fe. Argentina, eleodoro77@gmail.com

4. Professor, DSc. National University of Tucumán. Argentina, celiabrandan@gmail.com
\end{abstract}

Cite: Di Barbaro, G.; Andrada, H.; Del Valle, E.; Brandán, C. (2021). Biological activity of soils cultivated with yacón (Smallanthus sonchifolius), inoculated with Azospirillum brasilense and native mycorrhizal fungi. Revista de Ciencias Agrícolas. 38(1): 125-133. doi https://doi.org/10.22267/rcia.213801.148

Received: December 222020. Accepted: May 032021.

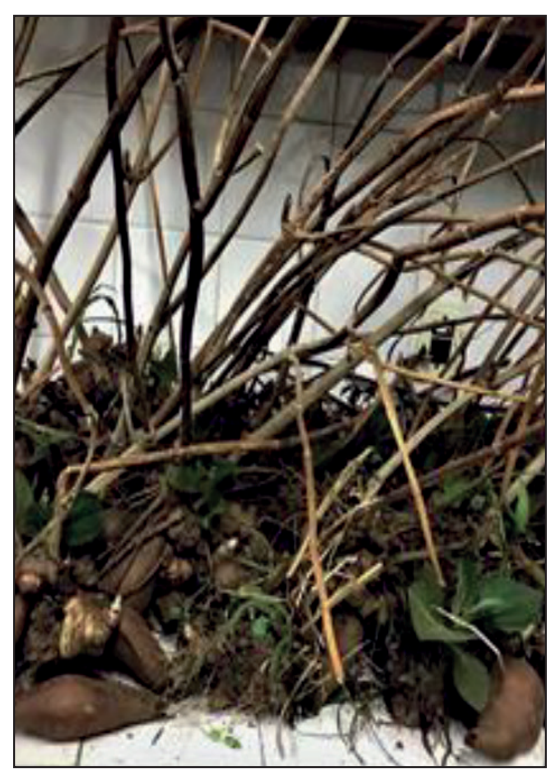

ABSTRACT

The soil is influenced by the roots of plants because the exudate radicals affect its physical, chemical, and biological processes. The aim of this research was to evaluate the microbial activity of soils cultivated with yacón (Smallanthus sonchifolius Poep. \& Endl) H. Robinson and inoculated with microorganisms which promote plant growth. The experimental design used was randomized blocks with three repetitions per treatment. Each repetition corresponded to a $3 \times 3 \mathrm{~m}$ plot with 25 plants, in 5 cultivation lines with a distance of $70 \mathrm{~cm}$ apart. Four treatments were applied at the time of plantation. These consisted of yacón propagules inoculated with Azospirillum brasilense (T1) and native mycorrhizal fungi (T2) inoculated with the microbial consortium (T3). In the control treatments, the propagules were not inoculated with these microorganisms (T0). Soil samples were collected in lots cultivated with yacón located in the Province of Catamarca, in the northwest of Argentina. The samples were collected at the time of implantation and harvest during three agricultural cycles. The total Biological Activity (TBA) of the collected samples was determined by Fluorescein Diacetate Hydrolysis. The TBA of the soil was affected by the different crop treatments, which rose in the analyzed soils and was statistically different from the control treatments. Significant differences were also observed between the TBA of the soils at the beginning of the crops in comparison with the recorded values of the crop at the time of harvest. The inoculation of yacón propagules with $A$. brasilense and native mycorrhizal fungi affects the TBA of the cultivated soils marking a significant increase.

Key words: Mycorrhizae; Microbial Consortium; Rhizosphere; Catamarca; Argentina.

\section{RESUMEN}

El suelo está influenciado por las raíces de las plantas, ya que los exudados radicales afectan los procesos físicos, químicos y biológicos del suelo. El objetivo de la investigación fue evaluar la actividad microbiana en suelos 
donde se ha cultivado yacón (Smallanthus sonchifolius), inoculado con microorganismos promotores del crecimiento de las plantas. El diseño experimental empleado fue bloques al azar con tres repeticiones por tratamiento. Cada repetición correspondió a una parcela de 3 x $3 \mathrm{~m}$ con 25 plantas, en 5 líneas de cultivo distanciadas a $70 \mathrm{~cm}$. Se aplicaron cuatro tratamientos en el momento de la plantación y consistieron en la inoculación de propágulos de yacón con Azospirillum brasilense (T1), hongos micorrícicos nativos (T2), con el consorcio microbiano (T3) y en los tratamientos testigos los propágulos sin inocular con estos microorganismos (T0). Muestras de suelo fueron colectadas en lotes cultivados con yacón situados en la Provincia de Catamarca, al noroeste de Argentina, al momento de implantación y de cosecha durante tres ciclos agrícolas. Se determinó la Actividad Biológica Total (ABT) por Hidrólisis del Diacetato de Fluoresceína a las muestras colectadas. La ABT del suelo fue afectada por los diferentes tratamientos del cultivo, la cual se elevó en los suelos estudiados, difiriendo estadísticamente con los testigos. También se observaron diferencias significativas entre la ABT de los suelos al inicio de los cultivos con los valores registrados a la cosecha de este. La inoculación de propágulos de yacón con A. brasilense y hongos micorrícicos nativos afecta la ABT de los suelos cultivados, aumentando significativamente.

Palabras clave: Micorrizas; Consorcio microbiano; Rizósfera; Catamarca Argentina.

\section{INTRODUCTION}

The soil has a large number and diversity of microorganisms responsible for its biological activity. The quality and quantity of plant material it has and the climatic factors affect microbial abundance, biodiversity, and their trophic relationships (Wright and Coleman, 2000). The microbial activity of the soil constitutes a measure of ecological importance, since on the one hand it represents the level of biological activity that involves the labile component of organic matter and, on the other, it integrates environmental factors and their influence on it (Zagal et al., 2002; Wing Ching-Jones and Uribe Lorío, 2016).

Nutrient recycling is influenced by the quality and quantity of plant material that enters the soil and by climatic and edaphic characteristics which also affect microbial abundance, the involved species, and their trophic composition (Wright \& Coleman, 2000; Di Ciocco et al., 2014). This means that the biological activities are bioindicators of soil quality (Alvear et al., 2007; Jaurixje et al., 2013).
Soil is a non-renewable natural resource, exposed to biotic and abiotic factors. The biological activity of soils is regulated by numerous enzymes and the microbial habitat and plant roots are affected by them (Makoi and Ndakidemi, 2008). The enzymes come from living organisms. Once they die, some resist and retain their activity in the soil for long periods. Soil enzymes not only play an important role in the chemical and biochemical environment, but they also have an effect on how fast nutrients are available to plants (Kannaiyan and Kumar, 2009).

All biological process occurring in the soil are enzymatic reactions (mineralization, immobilization, nitrogen fixation, nitrification, etc.); that is why the Total Biological Activity (TBA) is considered to be an index of soil fertility (Burns, 1982; Alvear et al., 2007).

There are numerous physical, chemical, biological, or biochemical factors to assess soil quality; these act as quality indicators. One of the biochemical parameters available to evaluate the biological activity of the soil is known as hydrolysis of fluorescein diacetate 
(FDA) (Adam and Duncan, 2001; Alvear et al., 2007; Perez et al., 2015). This measure of the enzymatic activity can be used to infer the microbiological activity of certain soils (Lillo et al., 2011), and it is a sensitive parameter for resource management practices (Makoi and Ndakidemi, 2008).

FDA is broken down by numerous enzymes, such as proteases, lipases, and esterases. Therefore, its hydrolysis is considered to be a general or broad spectrum indicator of biological soil activity (Bandick and Dick, 1999). The product of the enzymatic reaction is fluorescein, which can be observed under a fluorescence microscope, or it can be measured using a spectrophotometer (Green et al., 2006). For some time now, FDA hydrolysis has been used as an indicator of the active global microbial activity of soils under different types of management in order to determine which system favors global microbial activity (Alvear et al., 2007).

The cultivation of yacón (S. sonchifolius) dates back to pre-Columbian times. It has adapted to the ecological conditions of the Andean region, and it has been linked to the traditions of the people living there (Fernández et al., 2006; Mansilla et al., 2010). In recent years, it has gained interest for its nutraceutical properties, since it is a natural prebiotic, and also for having tubers rich in inulin (NiziolLukaszewska et al., 2010; Arnao et al., 2011; Satoh et al., 2013; Wagner et al., 2019). There are small producers of yacón in Argentina, specifically in the provinces of Jujuy and Salta (Manrique et al., 2005). They have found horticultural and medicinal uses for this species by commercializing the tubers.

The objective of the research was to evaluate the microbial activity of soils cultivated with yacón and inoculated with microorganisms which favor plant growth.

\section{MATERIALS AND METHODS}

This study was based on three trials of yacón crops during three years at places in the Central Valley of the Province of Catamarca, located in the semi-arid region of the northwest of the Argentine Republic. Sandy loam was the soil textural class of the sites were Yacón was cultivated (sand: 73.85; clay: 8\%; silt: $18.2 \%$; pH: 7.5; M.0.: 5.72\%).

In the plantations, propagules of yacón (Smallanthus sonchifolius) of around 30 grams each and the native soil microorganisms were used. The microorganisms were Azospirillum brasilense and mycorrhizal fungi, obtained from colonized forage species that acted as trap cultures (Di Barbaro et al., 2018).

An experimental design of randomized blocks with three repetitions per treatment was established in each trial. Each repetition corresponded to a $3 \times 3 \mathrm{~m}$ plot with 25 plants (experimental units), in 5 cultivation lines of 70 $\mathrm{cm}$ apart. The microbial inoculation treatments applied on the yacón propagules at the time of planting were: T0: Control or control (not inoculated); T1: Inoculation with A. brasilense; T2: Inoculation with native mycorrhizal fungi, and T3: Joint inoculation with $A$. brasilense and native mycorrhizal fungi.

As far as the inoculated treatments, the selected microorganisms were applied to the yacón propagules by sinking them in the inoculant just before plantation. In the meantime, the propagules of the control treatments were placed in sterile running water. 
The native strain Pi 8 of Azospirillum brasilense was used, isolated from the endorhizosphere of paprika (Capsicum annum var. Elephant trunk) grown in the Province of Catamarca, and biochemically and molecularly identified (Tarrand et al., 1978; Döbereiner et al., 1995; Caballero-Mellado, 2002). The concentration of $A$. brasilense used for the inoculations was of $5 \times 10^{7}$ azospirillum. $\mathrm{mL}^{-1}$ quantified in a Neubauer chamber (Manacorda et al., 2007).

The inoculum of mycorrhizal fungi native to the province consisted of roots of Melilotus officinalis L., Avena sativa L., Hordeum vulgare L., Secale cereale L., Panicum maximum Jacq. and Cenchrus ciliaris L. colonized by these. The percentage of mycorrhizal colonization of the roots used as inoculum was $81.38 \%$, estimated by the method of line intersections and microscopic observation of roots by Sieverding (1983) and McGonigle et al. (1990).

Soil samples were collected before planting the crop (T0) and at the time of harvest. The latter were collected from the rhizosphere of the plants using the set-up treatments. The collected samples were refrigerated at $4{ }^{\circ} \mathrm{C}$ and transferred to the Laboratory of Agricultural
Microbiology of the National University of Catamarca in order to determine the Total Biological Activity by hydrolysis of fluorescein diacetate (FDA).

The samples at the beginning of cultivation (T0) were taken between the months of October and November. Those at the end of the harvest were taken between May and July of each evaluated year. The evaluations of this research were carried out for 3 consecutive years, from 2017 to 2019, in different batches of production.

The biological activity was determined by the fluorescein diacetate hydrolysis (FDA) method according to Schnürer and Roswall (1982). Quickly, $5 \mathrm{~g}$ of the soil to be evaluated and $20 \mathrm{ml}$ of potassium phosphate buffer solution $60 \mathrm{mM}(\mathrm{pH} 7.6)$ are added in an Erlenmeyer flask. Then, $0.2 \mathrm{ml}$ of stock solution of FDA (2 $\mathrm{mg} / \mathrm{ml}$ of acetone) is added and incubated for 20 minutes with stirring $(200 \mathrm{rpm})$ at $25^{\circ} \mathrm{C}$. The reaction is then stopped by adding $20 \mathrm{ml}$ of acetone to the Erlenmeyer flask, filtered (Whatman filter paper \# 1) and read in a spectrophotometer at an absorbance of 490nm (Figure 1).



Figure 1. Procedure for the analysis of the total biological activity by hydrolysis of fluorescein diacetate. 
To obtain the FDA concentration, the standard curve was previously determined. In order to do this, solutions of concentration of known FDA $(0 \mu \mathrm{g}, 100 \mu \mathrm{g}, 200 \mu \mathrm{g}, 300 \mu \mathrm{g}$, and $400 \mu \mathrm{g})$ were prepared and subjected to complete hydrolysis. In measurements with the spectrophotometer, the relationship between absorbance $\left(\mathrm{A}^{\circ}\right)$ and concentration $([\mathrm{C}])$ of FDA was obtained. Then, the absorbance data obtained from the different soil samples taken from the crops were adjusted according to the standard curve.

The results were analyzed by analysis of variance (ANOVA) and the means were compared by means of Tukey's test at a significance level of $\alpha \leq 0.05$. Statistical analyzes were performed with the Infostat statistical program (Di Rienzo et al., 2018).

\section{RESULTS AND DISCUSSION}

The results of this research indicate that the biological activity of soils was influenced by microbial inoculation. The highest global enzymatic activity, measured as FDA hydrolysis, recorded statistical differences when microorganisms that promote plant growth were applied (Table 1).

The results are expressed as the mean + its standard error. Different letters indicate significant differences between treatments carried out in the same agricultural cycle according to the Tukey test $(p<0.05)$.

The highest TBA by ADF hydrolysis was recorded in soils cultivated with yacón inoculated with the microbial consortium of $A$. brasilense and mycorrhizal fungi. Statistically significant differences were obtained $(p<0.05)$ between the TBA values of $\mathrm{T} 3$ in relation to the soil samples from the moment before crop plantation and the soil samples cultivated with yacón corresponding to the control treatments without inoculation microbial (T0) (Table 1).

Table 1. Hydrolysis of ADF ( $\mu \mathrm{g} ; \mu \mathrm{g} \mathrm{gss}^{-1} \mathrm{~h}^{-1}$ ) in soils cultivated with yacón in three cultivation cycles in the province of Catamarca.

\begin{tabular}{|c|c|c|c|c|}
\hline \multirow{2}{*}{$\begin{array}{c}\text { Evaluation } \\
\text { moment }\end{array}$} & \multirow[t]{2}{*}{ Treatment } & \multicolumn{3}{|c|}{$\begin{array}{l}\text { Hydrolyzed FDA ( } \mu \mathrm{g}) \\
\left(\mu \mathrm{gss}^{-1} \mathrm{~h}^{-1}\right)\end{array}$} \\
\hline & & 2017-2018 & 2018-2019 & 2018-2019 \\
\hline Plantation & T0 & $\begin{array}{r}0,05 \pm 0,01 \mathbf{a} \\
0,02 \pm 0,004\end{array}$ & $\begin{array}{l}0,02 \pm 0,044 \mathbf{a} \\
0,008 \pm 0,0176\end{array}$ & $\begin{array}{l}0,02 \pm 0,036 \mathbf{a} \\
0,008 \pm 0,0144\end{array}$ \\
\hline \multirow{4}{*}{ Harvest } & $\mathrm{T} 1$ & $\begin{array}{l}0,12 \pm 0,02 \mathbf{a} \\
0,048 \pm 0,008\end{array}$ & $\begin{array}{l}0,04 \pm 0,035 \mathbf{a} \\
0,016 \pm 0,014\end{array}$ & $\begin{array}{l}0,04 \pm 0,028 \mathbf{a} \\
0,016 \pm 0,0112\end{array}$ \\
\hline & $\mathrm{T} 2$ & $\begin{array}{l}0,18 \pm 0,03 \mathbf{a b} \\
0,072 \pm 0,012\end{array}$ & $\begin{array}{l}0,19 \pm 0,01 \mathbf{b} \\
0,076 \pm 0,004\end{array}$ & $\begin{array}{l}0,25 \pm 0,04 \mathbf{b} \\
0,1 \pm 0,016\end{array}$ \\
\hline & T3 & $\begin{array}{l}0,15 \pm 0,03 \mathbf{a} \\
0,06 \pm 0,012\end{array}$ & $\begin{array}{l}0,17 \pm 0,02 \mathbf{b} \\
0,068 \pm 0,008\end{array}$ & $\begin{array}{l}0,24 \pm 0,01 \mathbf{b} \\
0,096 \pm 0,004\end{array}$ \\
\hline & $\mathrm{T} 4$ & $\begin{array}{l}0,22 \pm 0,02 \mathbf{b} \\
0,088 \pm 0,008\end{array}$ & $\begin{array}{l}0,24 \pm 0,02 \mathbf{c} \\
0,096 \pm 0,008\end{array}$ & $\begin{array}{l}0,25 \pm 0,02 \mathbf{b} \\
0,025 \pm 0,008\end{array}$ \\
\hline
\end{tabular}


The soil cultivated with yacón created differences in biological activity, recording the highest TBA values at harvest, while the lowest TBA values were determined prior to yacón plantation (T0). The results match those obtained in soils cultivated with topinambur (Helianthus tuberosus) (Di Barbaro et al., 2020).

When comparing the four treatments applied to the yacón culture, statistically significant differences between the treatments with the inoculation of the microbial consortium $(A$. brasilense and mycorrhizal fungi or $\mathrm{T} 3$ ) and the control or non-inoculated control (T0) were observed.

The greater biological activity observed with the microbial co-inoculation (T3) is explained because when the mycorrhiza is formed, the radical physiology and the exudates that these generate are altered and located in the soil associated with the yacón roots. Consequently, the surrounding microbial population is changed. This contributes to the nutrition of the plant as it explores a larger volume of soil and increases the microbial activity (Blanco and Salas, 1997; Brundrett, 2009). On the other hand, Azospirillum is a bacterial genus widely known for its ability to promote plant growth; its promoter substances stimulate root growth, which increases its nutrients and water absorption potential, key benefit for crops grown in arid and semi-arid regions (Bashan et al., 2007).

In treatments inoculated with $A$. brasilense (T1) and with mycorrhizal fungi (T2), a higher TBA was obtained as compared with treatments without inoculation (T0). However, the differences were not always statistically significant (Table 1). These results in lots grown with yacón crops are similar to those obtained in soils grown with topinambur crops (Di Barbaro et al., 2020).

Therefore, improving the quality of the microflora of agricultural soils from the incorporation of organisms selected for their contribution to the production and development of crops is an alternative that would result in better crops, increased yields, and soil fertility (Caballero-Mellado, 2002).

One of the environmental variables that influences the biological activity of the soil the most is temperature (Rodríguez-Gutiérrez, 2014). This variable increases the microbial growth in the mesophilic range (between 15 and $45^{\circ} \mathrm{C}$, with an optimum range between 30 and $40^{\circ} \mathrm{C}$ ), which is basically recorded during spring and summer seasons. However, the TBA of the soil samples at the time of harvest, taken during the months of the lowest temperatures in the Central Valley of the Province of Catamarca (late autumn and early winter), were higher than those recorded before planting during spring, mainly in the treatments with microbial inoculation (Table 1).

Long summers with high temperatures and short, cool, dry winters characterize the Central Valley of Catamarca. Throughout the year, the average temperature generally varies from 6 to $33^{\circ} \mathrm{C}$ (https://es.weatherspark. com/y/27905/Clima-promedio-en-SanFernando-del-Valle-de-Catamarca-Argentinaduring-all-the-a\%C3\% B10).

The TBA of the soils before planting the yacón crop (T0) in spring and the TBA at the end of the crop (T0) in autumn / winter are similar despite the difference in temperatures in each season. For this reason, it is believed that the effect of the yacón cultivation 
resulted in increased microbial activity to levels comparable and slightly higher to those recorded during spring, before plantation (Table 1). This may be due to the interactions occurring in the rhizosphere and the higher root growth that create greater enzymatic activity and elevate the content of organic matter.

The vegetation, as well as the exudates produced by some roots, change the physical and chemical properties of the soils associated with the roots. These specifically include the structure, the porosity, the $\mathrm{pH}$, and the redox potential, factors that together influence the density and activity of the microorganisms (IGAC, 1993; Sánchez de Prager, 2007). This explains the higher biological activity at the end of the crop despite the fact that the evaluation was carried out in late autumn and early winter, when the soil temperature is low $\left(<7^{\circ} \mathrm{C}\right)$ and the microbial populations decrease. Soil temperature influences root exudation which affects rhizosphere conditions. Outside the optimal range $\left(25-35^{\circ} \mathrm{C}\right)$, permeability is altered and metabolism and exudation are reduced (Sánchez de Prager, 2007), altering the biological activity of the soil.

The values obtained revealed a positive effect on the soil enzymes activity, explaining the results observed in this work. What is more, they reveal that, in most of soils, the microorganisms dominate their biological component and respond quickly to environmental changes (Sánchez de Prager, 2007; Rivero-Herrada et al., 2016; GómezFernández et al., 2017). They are essential in the multiple functions of the soil; they are part of almost every known metabolic reaction and constitute the driving forces that supply energy and nutrients (Paolini Gómez, 2017).

\section{CONCLUSION}

The inoculation of the yacón crop (Smallanthus sonchifolius) with the microbial consortium of $A$. brasilense and mycorrhizal fungi increase the TBA of soils associated to the yacón roots. This represents an agricultural management strategy destined to improve the fertility of cultivated soils.

Conflict of interest: The authors declare that there is no conflict of interest.

\section{BIBLIOGRAPHIC REFERENCES}

Adam, G.; Duncan, H. (2001). Development of a sensitive and rapid method for the measurement of total microbial activity using fluorescein diacetate (FDA) in a range of soils. Soil Biol. Biochem. 33:943-951.

Alvear, M.; Reyes, F.; Morales, A.; Arriagada, C.; Reyes, M. (2007). Actividad biológica y agregados estables al agua en dos tipos de formaciones vegetales de un bosque templado del Centro-Sur de Chile con perturbación antrópica. Ecol. Austral. 17: 113-122.

Arnao, I.; Seminario, J.; Cisneros, R.; Trabucco, J. (2011). Potencial antioxidante de 10 accesiones de yacón, Smallanthus sonchifolius (Poepp. \& Endl.) H. Robinson, procedentes de Cajamarca Perú. Anales de la Fac. de Medicina. doi: http:// dx.doi.org/10.15381/anales.v72i4.1075

Bandick, A.K.; Dick, P.R. (1999). Field management effects on soil enzyme activities. Soil Biol. Biochem. 31:1471-1479.

Bashan, L.; Holguin, G.; Glick, B.; Bashan, Y. (2007). Bacterias promotoras del crecimiento en plantas para propósitos agrícolas y ambientales. En: Ferrera-Cerrato R.; Alarcon, A.; Champer, C.A. Microbiología Agrícola: Hongos, bacterias, micro y macrofauna, control biológico, plantasmicroorganismos. Editorial Trillas: México. 170224p. 
Blanco, F.A.; Rooms, E.A. (1997). Micorrizas en la agricultura: Contexto mundial e investigación realizada en Costa Rica. Agron. Costarricense. 21(1): 55-67.

Brundrett, M. (2009). Mycorrhizas in Natural Ecosystems. Advances in ecological research. 21:171-313.

Burns, R.C. (1982). Enzyme activity in soil. Location and possible role in microbial ecology. Soil Biol. Biochem. 14:107-108.

Caballero-Mellado, J. (2002). El género Azospirillum. En Martinez, E.; Martínez, J. Microbios en línea. México: Univ. Nac. Autónoma de México.

Di Barbaro, G., Espeche, E., Manenti, L., Rizo, M., Andrada, H., Viale, S.; Batallán-Morales, S. (2018). Asociaciones micorrícicas entre hongos nativos y plantas forrajeras cultivadas en el Valle Central de Catamarca. $1^{\circ}$ Jornadas de Ciencia y Tecnología. FCA, UNCa. Recovered from http:// editorial.unca.edu.ar/Publicacione $\% 20$ on $\% 20$ line/CUADERNOS\%2 0DE\%20CATEDRA/ Jornad a $\% 20$ de \% 20 divulgacion / P D F / Resumen\%20-\%20Di\%20Barbaro.pdf

Di Barbaro, G.; Andrada, H.; Del Valle, E.; Brandán de Weht, C. (2020). Actividad biológica de suelos cultivados con topinambur inoculados con Azospirillum brasilense y hongos micorrícicos. FAVE Sección Ciencias Agrarias. 18(1): 33-41. doi: 10.14409/fa.v19i1.9451

Di Ciocco, C.A.; Sandler, R.V.; Falco, L.B.; Coviella, C.E. (2014). Actividad microbiológica de un suelo sometido a distintos usos y su relación con variables físico-químicas. Rev. Fac. Cs. Agrarias. 49(1): 73.

Di Rienzo, J.A.; Casanoves, F.; Balzarini, M.G.; Gonzalez, L.; Tablada, M.; Robledo, C.W. (2018). Manual del Usuario - Info Stat version 2018. InfoStat versión 2018. Retrieved from http:// www.infostat.com.ar

Fernández, E.C.; Viehmannová, I.; Lachman, J.; Milella, L. (2006). Yacon [Smallanthus sonchifolius (Poeppig \& Endlicher) H. Robinson]: a new crop in the Central Europe. Plant Soil Environ. 52(12):564-570.
Green, V.; Stott, D.; Diack, M. (2006). Assay for fluorescein diacetate hydrolytic activity: Optimization for soil sample. Soil Biol. Biochem. 38:693-701.

Gómez-Fernández, E.J.; Delgado-Romero, J.A.; González-Grau, J.M. (2017). Actividad microbiana del suelo: temperatura y contenido hídrico. XIV Reunión de la Red Nacional de Microorganismos Extremófilos, Ourense (Vigo), REDEX 2017. Recovered from https://digital.csic.es/ handle/10261/163063

IGAC-Instituto Geográfico Agustín Codazzi. (1993). Aspectos ambientales para el ordenamiento territorial del occidente del Departamento del Caquetá. Bogotá: INPA-IGAC.

Jaurixje, M.; Torres, D.; Mendoza, B.; Henríquez, M.; Contreras, J. (2013). Propiedades físicas y químicas del suelo y su relación con la actividad biológica bajo diferentes manejos en la zona de Quíbor, estado Lara. Biaogro. 25(1): 47-56.

Kannaiyan, S.; Kumar, K. (2009). Biological Fertilizers for Sustainable Rice Production. pp. 89-109. En: Rai, M.K. New York: The Haworth Press, Inc. 543p.

Lillo, A.; Ramírez, H.; Reyes, F.; Ojeda, N.; Alvear, M. (2011). Actividad biológica del suelo de bosque templado en un transecto altitudinal, Parque Nacional Conguillío (38으. S), Chile. Bosque (Valdivia). 32(1):46-56. doi: http://dx.doi. org/10.4067/S0717-92002011000100006

Makoi, J.; Ndakidemi, P. (2008). Selected soil enzymes: Examples of their potential roles in the ecosystem. African J. Biotechnol. 7(3):181191.

Manrique, I.; Párraga, A.; Hermann, M. (2005). Yacón syrup: Principles and processing (8B). Conservación y uso de la biodiversidad de raíces y tubérculos andinos: Una década de investigación para el desarrollo (1993-2003). Centro Internacional de la Papa: Lima, Perú. 31p.

Manacorda, A.M.; Cuadros, D.P.; Álvarez, A. (2007). Manual Práctico de Microbiología - Tomo I: Microbiología Ambiental I. En: Manacorda, A.M.; Cuadros, D.P.; Álvarez, A. Recuento de Microorganismos. pp.48-54. Buenos Aires: Universidad Nacional del Comahue. 
Mansilla, R.; López, C.; Flores, M.; Mirror, R. (2010). Estudios de la biología reproductiva en cinco accesiones de Smallanthus sonchifolius (Poepp. \& Endl.) Robinson. Ecología Aplicada. 9(2): 167-175.

McGonigle, T.P.; Miller, M.H.; Evans, D.G.; Fairchild, G.L.; Swan, J.A. (1990). A new method which gives an objective measure of colonization of roots by vesicular-arbuscular mycorrhizal fungi. New Phytol. 115:495-501.

Niziol-Lukaszewska, Z.; Bujak, T.; Wasilewski, T.; Szmuc, E. (2010). Inulin as an effectiveness and safe ingredient in cosmetics. Pol.J. Chem. Technol. 21(1): 44-49. doi: https://doi.org/10.2478/ pjct-2019-0008

Paolini, J.E. (2017). Actividad microbiológica y biomasa microbiana en suelos cafetaleros de los Andes venezolanos. Terra Latinoamericana. 36(1): 13-22. doi: https://doi.org/10.28940/ terra.v36i1.257

Perez, M.M.; Masseroni, M.L.; Sartor, P.D.; Merini, L. (2015). Actividad biológica en suelos con diferentes prácticas agrícolas bajo riego en Colonia 25 de Mayo, La Pampa. A.A.S. Recovered from https://inta.gob.ar/sites/default/files/ inta-actividad_biologica_en__ suelos_con_ diferentes_practicas_agricilas_bajo_riego_en_ colonia_25_de_mayo_2.pdf

Rivero-Herrada, M.; Gaibor-Fernández, R.R.; Mozena-Leandro, W.; by Brito Ferreira E.P.; Ferraresi T.M.; Reyes Pérez J.J. (2016). Evaluación de atributos biológicos de un suelo latosol bajo producción agroecológica. Centro Agríc. 43(4): 14-20.

Rodríguez-Gutiérrez, N.M. (2014). Evaluación de la actividad microbiana global de un suelo bajo dossistemas de manejo, orgánicoy convencional. Recovered from http://repositorio.uchile.cl/ handle/2250/148408

Sánchez de Prager, M. (2007). La rizósfera: estrategia de colonización del suelo. En: Sánchez de Prager, M. Las Endomicorrizas: Expresión bioedáfica de importancia en el trópico. Ed. Capítulo 3. Palmira: Universidad Nacional de Colombia. 352p.
Satoh, H.; Audrey-Nguyen, M.T.; Kudoh, A.; Watanabe, T. (2013). Yacon diet (Smallanthus sonchifolius, Asteraceae) improves hepatic insulin resistance via reducing Trb3 expression in Zucker fa/fa rats. Nutrit. \& Diabetes. 3(5):e70. doi: 10.1038/nutd.2013.11

Schnürer, J.; Rosswall, T. (1982). Fluorescein diacetate hydrolysis as a measure of total microbial activity in soil and litter. Appl. Environ Microbiol. 43:1256-1261.

Sieverding, E. (1983). Proyecto Micorriza. Cali. Colombia: Centro Internacional de Agricultura Tropical. 121p.

Wagner, M.; Kamp, L.; Grae-Hönninger, S.; Lewandowski, I. (2019). Environmental and economic performance of Yacon (Smallanthus sonchifolius) cultivated forfructooligosaccharide production. Sustainability. 11(17): 4581. doi: https://doi.org/10.3390/su11174581

WingChing-Jones, R.; Uribe-Lorío, L. (2016). Biomasa y actividad microbiana en suelos de uso ganadero y en regeneración de bosque. Cuadernos de Investigación UNED. 8(1): 106114.

Wright, C.J.; Coleman, D.C. (2000). Cross-site comparasion of soil microbial biomass, soil nutrient status, and nematode trophic groups. Pedobiol. 44:2-23.

Zagal, E.; Rodríguez, N.; Vidal, I.; Quezada, L. (2002). Actividad microbiana en un suelo de origen volcánico bajo distinto manejo agronómico. Agricultura Técnica. 62(2): 297309. doi: https://dx.doi.org/10.4067/S036528072002000200012 